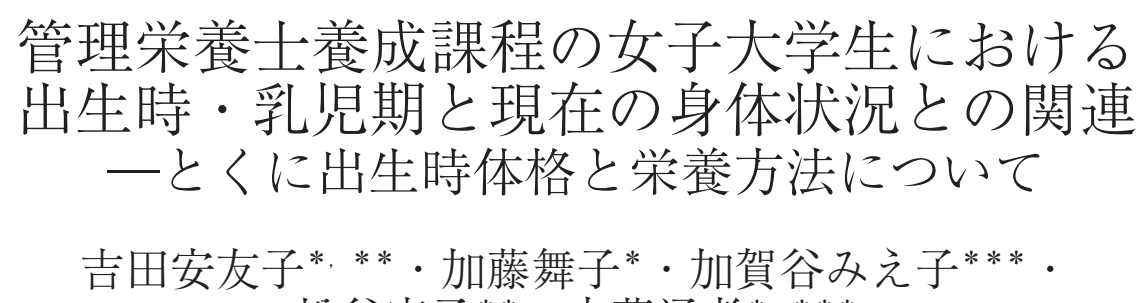

松谷康子** ${ }^{*}$ 内藤通孝

(*椙山女学園大学大学院生活科学研究科, $* *$ 修文大学健康栄養学部, $* * *$ 椙山女学園大学生活科学部)

(平成29年 6 月 7 日受付，平成29年 9 月 22 日受理)

\title{
Relation of the physical conditions at birth and in infancy to the current status in the female university students aiming for a registered dietitian - Physique at birth and feeding methods in infancy
}

\author{
Ayuko Yoshida*,**, Maiko Kato*, Mieko Kagaya***, \\ Yasuko Matsutani**, Michitaka Naito* \\ * Graduate School of Life Studies, Sugiyama Jogakuen University, \\ 17-3, Motomachi, Hoshigaoka, Chikusa-ku, Nagoya-shi, Aichi 464-8662 \\ ** Faculty of Health and Nutrition, Shubun University, \\ 6, Nikko-cho, Ichinomiya-shi, Aichi, 491-0938 \\ *** School of Life Studies, Sugiyama Jogakuen University, \\ 17-3, Motomachi, Hoshigaoka, Chikusa-ku, Nagoya-shi, Aichi 464-8662
* ***T464-8662 愛知県名古屋市千種区星が丘元町 17- 3
*** 491-0938 愛知県一宮市日光町 6 番地

\begin{abstract}
Aim: We investigated the relation of the physical conditions at birth and in infancy to the present status in the female university students, and examined the influence of feeding methods in infancy on current health condition.

Methods: We conducted anthropometric measurements for 52 female university students in the course for registered dietitian, and examined the relation of the physique at birth and during infancy to the current status. The conditions around birth and infancy were investigated using a "boshi-kenko-techo" (maternity health record book).

Results: Birth weight was found to have no effect on the current physical condition. Although birth weight was significantly lower in the group with less maternal gestational weight gain, but did not have a significant effect on the current physical condition. Visceral fat area and skinfold thickness were significantly lower in the absolute breast milk feeding group compared to the groups with other feeding methods such as bottle feeding and mixed feeding, suggesting that breast milk feeding up to age 3 months may be important. With respect to birth order, skinfold thickness was significantly lower in the second-born students than in the first-born.

Conclusions: Physical condition at birth did not affect the current physical condition; however, the difference of nutritional methods in infancy may have influenced on it, particularly visceral and subcutaneous fat volume. Although longitudinal studies are
\end{abstract}


necessary to elucidate the effect of nutrition during infancy on subsequent physique, it may be important to provide correct information on pregnancy, delivery, and child rearing.

\section{1. 緒言}

わが国では，1980年以降，低出生体重児の割合が増加 し続けており,「平成27年人口動態調査」では9.5\%であっ た ${ }^{1,2)}$ 。その背景として，20歳代女性に扔ける「やせ」 の割合が高いこと ${ }^{3)}$, 娃娠中に扔けるエネルギー・栄養 素摂取量の減少 ${ }^{4)}$, 高齢出産の増加などが要因として挙 げられている ${ }^{5,6)}$ 。成人期を迎える女性にとって, 出生 時掞よび乳児期の状況が将来（すなわち, 現在掞よび, それ以降）に及ぼす影響については不明な点が多く，解 明すべき重要な課題である。本研究では，管理栄養士養 成課程の女子大学生を対象に, 現在の身体状況と出生 時・乳児期の状況との関連について検討を行った。

母乳栄養については，将来の生活習慣病に対する予防 効果があるとされ，その重要性が指摘されている ${ }^{7-11)}$ 。 母乳栄養の推進は，1975年に当時の厚生省によって母乳 育児推進の 3 つのスローガン ${ }^{12}$ が提唱されたのをはじめ として, 厚生労働省の「授乳・離乳の支援ガイド ${ }^{132}$, 世界保健機関・国連児童基金の「母乳育児を成功させる ための10力条 $1^{14)}$ 等,さまざまな取り組みが行われてきた。 しかし，「平成27年乳幼児栄養調査」では，「母乳が出れ ば母乳で育てたい」(50.4\%) と「ぜひ母乳で育てたい」 （43.0\%）を合わせると，妊娠中には93.4\%が母乳育児 を希望しているにもかかわらず，生後 3 か月における母 乳育児は，わずか $54.7 \%$ であると報告されている ${ }^{15}$ 。そ こで, 本研究では, 乳児期における母乳栄養, 混合栄養, 人工栄養（以下，栄養方法とする）の違いが管理栄養士 養成課程の女子大学生の現在の身体状況に及ほす影響を 併せて検討した。

\section{2. 方 法}

\section{(1) 対象}

調査対象は, 名古屋市内の女子大学管理栄養学科 2 年 生108名のうち, 事前に調査の主旨拈よび調査方法を説 明し，文章による同意を得られた 52 名（19 00.2 歳）と した。本調査への参加は, 自由意志に基づくものであり 同時に採血を行ったため, 同意率が $48.2 \%$ と低值であっ た。調査時期は，2013年 5 月〜 6 月である。出生時・乳 児期の状況は母子健康手帳を用いて調査した。各解析の 群分けは，デー夕久損者を除いた者を対象とした。なお 本研究の研究計画は, 予め椙山女学園大学生活科学部研 究倫理審査委員会の承認を得た（承認番号2013-4)。

\section{（2）方 法}

\section{1 ）栄養素等摂取量}

習慣的な食事摂取状況を把握するため, 秤量目安記録 法を用い，調查開始前の 3 日間実施した。被験者には, 自記式で記録用紙に食事をした時間・場所・誰と食事を したか・料理名・食材料名・重量の記入を依頼した。食 品の重量は可能な限り秤量し, 秤量が困難な場合のみ目 安量の記入とした。また，市販食品は商品名抢よび栄養 成分がわかるものに関しては記入も依頼した。食事摂取 前に目安となるスケールとともに写真撮影を依頼した。 エクセル栄養君 ver.6.0（建帛社）を用いて栄養価計算 を行い，エネルギー，たんぱく質，脂質，炭水化物，ナ トリウム，食塩相当量等を算出した。

\section{2 ) 現在の身体状況}

身長，ウエスト，ヒップ，皮下脂肪厚（上腕三頭筋部 皮下脂肪厚 +肩甲骨下部皮下脂肪厚) (竹井機器工業) を 3 年以上の経験がある管理栄養士が測定し，体構成成 分分析装置 InBody720（バイオスペース）を用いて体重 BMI（Body Mass Index）, 体脂肪量, 骨格筋量, 内臓脂 肪断面積を測定した。測定条件として, 前日からの暴领 暴食, サプリメントの摄取をしないこと，前日21時以降 は絶食とした。

\section{3 ）母子健康手帳}

母子健康手帳を用いて, 対象者の母親の娃娠中の健康 状態, 出生時状況, 栄養方法, 出生時から 3 歳までの健 康診査結果などの情報を得た。

\section{4 ) 統計解析}

結果は, 出生時体重別解析では, 中央值士四分位偏差, 第 1 四分位数, 第 3 四分位数で示した。その他の解析で は, 平均土標準偏差で示した。統計解析は, IBM SPSS Statistics 21（日本アイ・ビー・エム）を用い, すべて 危険率 5 \%未満を有意とした。Shapiro-Wilk test で正規 性を確認後, 出生時体重別解析では, Kruskal-Wallis test， Mann-Whitney $U$ test を行い，多重性は Bonferroni の補正で調整した。妊娠期体重増加量別解析と栄養方法 別解析では, Scheffe's $F$ test を行った。出生順位別解析 では，対応なしの $t$ 検定を行った。

\section{3. 結果}

\section{（1）対象者集団の現在の身体状況および栄養素等摂取}

\section{量}

対象者52名の現在の身体状況掞よび栄養素等摂取量を 平均土標準偏差，範囲（最小值一最大値）で示した（表 1 )。現在の身長は $157.9 \pm 5.3 \mathrm{~cm}$, 体重は51.3 $36.9 \mathrm{~kg}$, BMI は20.5 52.3 , 皮下脂肪厚（上腕三頭筋部皮下脂肪 
表 1 対象者集団の現在の身体状況および栄養素等摂取量

\begin{tabular}{|c|c|c|}
\hline & 平均土標準偏差 & 範囲（最小值－最大值） \\
\hline \multicolumn{3}{|l|}{ 出生時·乳児期状況 } \\
\hline 出生時体重（g） & $3,104 \pm 435$ & $1,580-4,250$ \\
\hline 1 歳時体重（g） & $9,124 \pm 815$ & $7,305-10,800$ \\
\hline 在胎期間（週） & $39 \pm 1$ & $32-42$ \\
\hline 母親の年齢（歳） & $28.6 \pm 3.2$ & $24.0-37.0$ \\
\hline 母親の BMI（ $\left(\mathrm{kg} / \mathrm{m}^{2}\right)^{*}$ & $20.7 \pm 2.0$ & $16.8-24.9$ \\
\hline \multicolumn{3}{|l|}{ 現在の状況 } \\
\hline 身長（cm） & $157.9 \pm 5.3$ & $148.0-169.0$ \\
\hline 体重（kg） & $51.3 \pm 6.9$ & $42.4-76.1$ \\
\hline BMI $\left(\mathrm{kg} / \mathrm{m}^{2}\right)$ & $20.5 \pm 2.2$ & $16.9-30.1$ \\
\hline ウエスト / ヒップ比 & $0.80 \pm 0.06$ & $0.66-0.94$ \\
\hline 体脂肪量（ $\mathrm{kg} / \mathrm{kg}$ 体重） & $0.26 \pm 0.05$ & $0.14-0.43$ \\
\hline 骨格筋量 $(\mathrm{kg} / \mathrm{kg}$ 体重） & $0.40 \pm 0.03$ & $0.31-0.47$ \\
\hline 内臓脂肪断面積 $\left(\mathrm{cm}^{2}\right)$ & $21.9 \pm 13.6$ & $5.0-72.3$ \\
\hline 皮下脂肪厚（mm） & $32.5 \pm 9.2$ & $17.0-60.0$ \\
\hline \multicolumn{3}{|l|}{ 主な栄養素等摂取状況 } \\
\hline エネルギー (kcal) & $1557 \pm 305$ & $1005-2296$ \\
\hline たんぱく質（g） & $57.7 \pm 11.6$ & $29.1-82.6$ \\
\hline 脂質（g） & $53.8 \pm 16.4$ & $22.9-125.1$ \\
\hline 炭水化物（g） & $207.8 \pm 50.5$ & $128.8-362.6$ \\
\hline 鉄 $(\mathrm{mg})$ & $6.2 \pm 2.5$ & $2.9-14.6$ \\
\hline カルシウム (mg) & $362 \pm 143$ & $129-305$ \\
\hline マグネシウム（mg） & $195 \pm 65$ & $86-243$ \\
\hline カリウム $(\mathrm{mg})$ & $1817 \pm 635$ & $946-1532$ \\
\hline 食物繊維（g） & $10.8 \pm 4.3$ & $4.2-9.1$ \\
\hline 食塩相当量（g） & $7.0 \pm 2.4$ & $2.4-13.4$ \\
\hline
\end{tabular}

厚＋肩甲骨下部皮下脂肪厚) は, $32.5 \pm 9.2 \mathrm{~mm}$ であった。 BMI 18.5未満の者は 6 名で, BMI 25 以上の者はいな かった。栄養素等摂取量は, エネルギーは1557 305

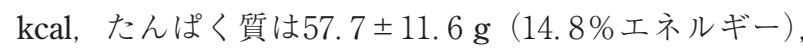
脂質は $53.8 \pm 16.4 \mathrm{~g}$ (31\%エネルギー), 炭水化物は $207.8 \pm 50.5 \mathrm{~g}$ (53.3\%エネルギー) であった。

\section{（2）女子大学生の出生時および乳児期の身体状況と現 在の身体状況との関連}

\section{1) 出生時体重別解析（表 2)}

出生時体重を基準に，三分位法により，第 1 分位 (2, $950 \mathrm{~g}$ 未満, 16名)，第 2 分位 $(2,950 \mathrm{~g}$ 以上 $3,300 \mathrm{~g}$ 未満, 17 名), 第 3 分位 (3, $300 \mathrm{~g}$ 以上, 16名) の 3 群 に分け, 各項目について比較した。その結果, 1 歳時体 重は第 1 分位が第 3 分位に比べて有意に軽かった $(p<$ 0.05)。現在の身体状況および栄養素等摂取量においては, 3 群間で有意差はみられなかった（結果示さず）。

\section{2 ) 妊娠期体重増加量別解析（表 3 ）}

厚生労働省による「妊産婦のための食生活指針」16) では, 非妊娠時の体格区分によって, 推奨体重増加量が示され ており, BMI 18.5未満では 9〜12 kg, BMI 18.5以上 25. 0未満では $7 \sim 12 \mathrm{~kg}$, BMI 25. 0以上では個別対応と されている。この範囲に従い, 妊娠中の体重増加量が推 奨体重増加量より少ない者を「少ない群」（８名), 範囲
内の者を「適正群」(23名), 推奨増加量よりも多い者を 「多い群」(11名）の 3 群に分け, 各項目について比較し た。なお，非妊娠時に「肥満」(BMI 25以上) に該当す る者はいなかった。その結果, 出生時体重は,「少ない群」 が「適正群」 $(p<0.01)$, 「多い群」 $(p<0.001)$ に比べ て有意に軽かった。1歳時体重は,「少ない群」が「多 い群」に比べて有意に軽かった $(p<0.05)$ 。現在の身 体状況および栄養素等摂取量は 3 群間に有意差はみられ なかった（結果示さず）。

\section{（３）栄養方法の違いによる現在の身体状況への影響}

\section{1 ) 栄養方法別解析 (表 4)}

天冨ら ${ }^{17)}$ を参考に，3 3 月時点までの栄養方法に着目 して以下のように群分けをし，各項目について比較した。 生後 3 か月間母乳栄養のみであったもの（I 群，12名）, 人工栄養や混合栄養などの経過を経て, 生後 3 か月時点 において母乳栄養であったもの（II 群, 13名), 生後 3 か月までの間に母乳のみで栄養した時期が一時的にあっ たが，生後 3 か月時点において混合栄養または人工栄養 であったもの（III群，9名）, 生後 3 か月間一度も母乳 のみで栄養した時期がなかったもの（IV 群，15名）の 4 群に分け, 各項目について比較した。その結果, 出生時 および 1 歳時体重において 4 群間に有意差はみられな かった。内臓脂肪断面積は, I 群が II 群 $(p<0.01)$ お 
表 2 出生時体重別解析

\begin{tabular}{|c|c|c|c|}
\hline & 第 1 分位 & 第 2 分位 & 第 3 分位 \\
\hline 出生時体重範囲（g） & $<2,950$ & $2,950 \leq-<3,300$ & $\geq 3,300$ \\
\hline $\begin{array}{l}\text { 人数 (人) } \\
\text { 出生時·乳児期状況 }\end{array}$ & $16(32.7 \%)$ & $17(34.6 \%)$ & $16(32.7 \%)$ \\
\hline 出生時体重（g） & $\begin{array}{r}2,740 \pm 165^{* * *} \\
(2,531-2,860)\end{array}$ & $\begin{array}{c}3,094 \pm 72^{* * *} \\
(3,040-3,184)\end{array}$ & $\begin{array}{l}3,458 \pm 74^{* * *} \\
(3,369-3,516)\end{array}$ \\
\hline 1 歳時体重（g） & $\begin{array}{l}8,682 \pm 325 \\
(8,350-9,000)\end{array}$ & $\begin{array}{l}9,300 \pm 470 \\
(8,875-9,815)\end{array}$ & $\begin{array}{l}9,650 \pm 300^{*} \\
(9,500-10,100)\end{array}$ \\
\hline 在胎期間（週） & $\begin{array}{l}39 \pm 1 \\
(38-40)\end{array}$ & $\begin{array}{l}39 \pm 1 \\
(38-39)\end{array}$ & $\begin{array}{l}39 \pm 1 \\
(39-40)\end{array}$ \\
\hline 母親の年齢（歳） & $\begin{array}{l}27.5 \pm 1.3 \\
(26.8-29.3)\end{array}$ & $\begin{array}{l}27.0 \pm 1.5 \\
(26.0-29.0)\end{array}$ & $\begin{array}{l}29.0 \pm 3.3 \\
(26.3-32.8)\end{array}$ \\
\hline 母親の BMI（kg/m $\left.{ }^{2}\right)^{*}$ & $\begin{array}{l}21.1 \pm 1.8 \\
(18.7-22.4)\end{array}$ & $\begin{array}{c}19.9 \pm 0.8 \\
(19.1-20.7)\end{array}$ & $\begin{array}{l}21.7 \pm 1.5 \\
(20.0-23.1)\end{array}$ \\
\hline \multicolumn{4}{|l|}{ 現在の状況 } \\
\hline 身長（cm） & $\begin{array}{l}155.4 \pm 4.4 \\
(151.6-160.5)\end{array}$ & $\begin{array}{l}160.0 \pm 1.9 \\
(158.0-161.7)\end{array}$ & $\begin{array}{l}158.0 \pm 4.0 \\
(154.2-162.3)\end{array}$ \\
\hline 体重（kg） & $\begin{array}{c}47.6 \pm 5.2 \\
(433.3-53.7)\end{array}$ & $\begin{array}{l}52.5 \pm 4.5 \\
(46.2-55.1)\end{array}$ & $\begin{array}{l}53.6 \pm 3.0 \\
(49.9-56.0)\end{array}$ \\
\hline BMI $\left(\mathrm{kg} / \mathrm{m}^{2}\right)$ & $\begin{array}{l}19.9 \pm 0.8 \\
(19.1-20.7)\end{array}$ & $\begin{array}{l}20.0 \pm 1.4 \\
(18.6-21.4)\end{array}$ & $\begin{array}{l}21.4 \pm 1.4 \\
(20.1-22.8)\end{array}$ \\
\hline ウエスト / ヒップ比 & $\begin{array}{c}0.80 \pm 0.04 \\
(0.76-0.85)\end{array}$ & $\begin{array}{c}0.79 \pm 0.05 \\
(0.76-0.85)\end{array}$ & $\begin{array}{c}0.82 \pm 0.04 \\
(0.79-0.86)\end{array}$ \\
\hline 体脂肪量 $(\mathrm{kg} / \mathrm{kg}$ 体重 $)$ & $\begin{array}{c}0.26 \pm 0.02 \\
(0.24-0.28)\end{array}$ & $\begin{array}{c}0.25 \pm 0.04 \\
(0.21-0.29)\end{array}$ & $\begin{array}{c}0.27 \pm 0.03 \\
(0.24-0.30)\end{array}$ \\
\hline 骨格筋量 $(\mathrm{kg} / \mathrm{kg}$ 体重 $)$ & $\begin{array}{c}0.40 \pm 0.01 \\
(0.39-0.40)\end{array}$ & $\begin{array}{c}0.41 \pm 0.02 \\
(0.38-0.43)\end{array}$ & $\begin{array}{c}0.39 \pm 0.02 \\
(0.38-0.41)\end{array}$ \\
\hline 内臓脂肪断面積 $\left(\mathrm{cm}^{2}\right)$ & $\begin{array}{l}19.0 \pm 9.0 \\
(11.8-29.8)\end{array}$ & $\begin{array}{l}23.5 \pm 10.6 \\
(8.0-29.2)\end{array}$ & $\begin{array}{c}24.2 \pm 11.1 \\
(10.9-33.1)\end{array}$ \\
\hline 皮下脂肪厚 $(\mathrm{mm})$ & $\begin{array}{l}30 \pm 6 \\
(25-36)\end{array}$ & $\begin{array}{l}31 \pm 4 \\
(28-35)\end{array}$ & $\begin{array}{l}34 \pm 5 \\
(29-39)\end{array}$ \\
\hline
\end{tabular}

検定は，Kruskal-Wallis test，Mann-Whitney $U$ test を行い，Bonferroni の補正を行った。

すべての值は，中央値 \pm 四分位偏差（第 1 四分位数 - 第 3 四分位数）で示した。

*非妊娠時

${ }^{*} p<0.05$ （1 歳時体重）第 1 分位 vs. 第 3 分位

${ }^{* * *} p<0.001$ (出生時体重) 第 1 分位 vs. 第 2 分位，第 3 分位。第 2 分位 vs. 第 3 分位

表 3 妊娠期体重増加量別解析

\begin{tabular}{lccc}
\hline & 少ない群 & 適正群 & 多い群 \\
\hline 人数 $($ 人) & $8(19.0 \%)$ & $23(54.8 \%)$ & $11(26.2 \%)$ \\
出生時・乳児期状況 & & & $3,323 \pm 238^{* * *}$ \\
出生時体重 $(\mathrm{g})$ & $2,737 \pm 219$ & $3,144 \pm 320^{* * *}$ & $9,659 \pm 691^{*}$ \\
1歳時体重 $(\mathrm{g})$ & $8,621 \pm 638$ & $9,251 \pm 608$ & $158.6 \pm 4.5$ \\
現在の状況 & & & $55.1 \pm 8.3$ \\
身長 $(\mathrm{cm})$ & $158.4 \pm 4.8$ & $158.0 \pm 6.2$ & $21.9 \pm 3.2$ \\
体重 $(\mathrm{kg})$ & $49.0 \pm 4.9$ & $51.5 \pm 6.4$ & $0.82 \pm 0.04$ \\
BMI $\left(\mathrm{kg} / \mathrm{m}^{2}\right)$ & $19.5 \pm 1.1$ & $20.6 \pm 1.9$ & $0.26 \pm 0.07$ \\
ウエスト $/$ ヒップ比 & $0.79 \pm 0.05$ & $0.82 \pm 0.05$ & $0.40 \pm 0.04$ \\
体脂肪量 $(\mathrm{kg} / \mathrm{kg}$ 体重 $)$ & $0.25 \pm 0.02$ & $0.25 \pm 0.05$ & $25.6 \pm 20.3$ \\
骨格筋量 $(\mathrm{kg} / \mathrm{kg}$ 体重 $)$ & $0.40 \pm 0.01$ & $0.40 \pm 0.03$ & $33 \pm 11$ \\
内臟脂肪断面積 $\left(\mathrm{cm}^{2}\right)$ & $21.9 \pm 9.7$ & $21.5 \pm 12.2$ & $33 \pm 11$ \\
皮下脂肪厚 $(\mathrm{mm})$ & $30 \pm 5$ & & \\
\hline
\end{tabular}

検定は, Scheffe's $F$ test で行った。

すべての值は，平均值士標準偏差で示した。

* $p<0.05$ ( 1 歳時体重) 少ない群 vs. 多い群

** $p<0.01$ (出生時体重) 少ない群 vs. 適正群

${ }^{* * *} p<0.001$ (出生時体重) 少ない群 vs. 多い群 
表 4 栄養方法別解析

\begin{tabular}{|c|c|c|c|c|}
\hline & I 群 & II 群 & III群 & IV 群 \\
\hline 人数（人） & $12(24.5 \%)$ & $13(26.5 \%)$ & $9(18.4 \%)$ & $15(30.6 \%)$ \\
\hline \multicolumn{5}{|l|}{ 出生時 · 乳児期状況 } \\
\hline 出生時体重（g） & $3,132 \pm 542$ & $3,172 \pm 332$ & $3,025 \pm 228$ & $3,115 \pm 488$ \\
\hline 1 歳時体重（g） & $8,957 \pm 834$ & $9,584 \pm 640$ & $8,911 \pm 200$ & $9,056 \pm 886$ \\
\hline \multicolumn{5}{|l|}{ 現在の状況 } \\
\hline 身長（cm） & $157.2 \pm 5.7$ & $159.8 \pm 4.8$ & $157.2 \pm 5.9$ & $156.7 \pm 8.6$ \\
\hline 体重（kg） & $48.9 \pm 4.8$ & $53.4 \pm 4.9$ & $51.3 \pm 7.6$ & $51.6 \pm 8.6$ \\
\hline BMI $\left(\mathrm{kg} / \mathrm{m}^{2}\right)$ & $19.8 \pm 1.2$ & $20.9 \pm 1.8$ & $20.7 \pm 2.2$ & $20.9 \pm 3.1$ \\
\hline ウエスト / ヒップ比 & $0.78 \pm 0.05$ & $0.80 \pm 0.04$ & $0.83 \pm 0.06$ & $0.81 \pm 0.06$ \\
\hline 体脂肪量（kg/kg 体重） & $0.23 \pm 0.05$ & $0.26 \pm 0.05$ & $0.26 \pm 0.05$ & $0.26 \pm 0.05$ \\
\hline 骨格筋量（kg/kg 体重） & $0.42 \pm 0.03$ & $0.40 \pm 0.03$ & $0.39 \pm 0.02$ & $0.40 \pm 0.0 .3$ \\
\hline 内臓脂肪断面積 $\left(\mathrm{cm}^{2}\right)$ & $13.3 \pm 8.3$ & $27.5 \pm 12.0^{* *}$ & $23.6 \pm 12.9$ & $23.7 \pm 15.7^{*}$ \\
\hline 皮下脂肪厚（mm） & $26 \pm 6$ & $36 \pm 8^{* *}$ & $36 \pm 11^{* *}$ & $34 \pm 8 *$ \\
\hline
\end{tabular}

検定は, Scheffe’s $F$ test で行った。

すべての值は, 平均值土標準偏差で示した。

${ }^{*} p<0.05$ (内臓脂肪断面積, 皮下脂肪厚) I 群 vs. IV 群

${ }^{* *} p<0.01$ (内臓脂肪断面積） I 群 vs. II 群。（皮下脂肪厚） I 群 vs. II 群， III群

表 5 出生順位別解析

\begin{tabular}{lcc}
\hline & 第 1 子群 & 第 2 子以降群 \\
\hline 人数 $($ 人) & $21(44.7 \%)$ & $26(55.3 \%)$ \\
出生時·乳児期状況 & & \\
出生時体重 $(\mathrm{g})$ & $3,041 \pm 441$ & $3,191 \pm 431$ \\
$\quad$ 歳時体重 $(\mathrm{g})$ & $9,412 \pm 682$ & $8,939 \pm 749$ \\
現在の状況 & & \\
身長 $(\mathrm{cm})$ & $157.7 \pm 5.1$ & $157.8 \pm 5.6$ \\
体重 $(\mathrm{kg})$ & $51.4 \pm 5.6$ & $50.2 \pm 5.8$ \\
BMI $\left(\mathrm{kg} / \mathrm{m}^{2}\right)$ & $20.7 \pm 2.1$ & $20.3 \pm 2.7$ \\
ウエスト / ヒップ比 & $0.82 \pm 0.04$ & $0.80 \pm 0.06$ \\
体脂肪量 $(\mathrm{kg} / \mathrm{kg}$ 体重 $)$ & $0.27 \pm 0.04$ & $0.25 \pm 0.04$ \\
骨格筋量 $(\mathrm{kg} / \mathrm{kg}$ 体重) & $0.40 \pm 0.02$ & $0.40 \pm 0.02$ \\
内臟脂肪断面積 $\left(\mathrm{cm}^{2}\right)$ & $24.4 \pm 17.3$ & $19.2 \pm 11.1$ \\
皮下脂肪厚 $(\mathrm{mm})$ & $35 \pm 10$ & $30 \pm 7 * *$ \\
\hline
\end{tabular}

検定は，対応なしの $t$ 検定で行った。

すべての值は, 平均値士標準偏差で示した。

${ }^{* *} p<0.01$ (皮下脂肪厚) 第 1 子群 vs. 第 2 子以降群

よびIV群（ $p<0.05 ）$ と比較して有意に低值を示し， III 群と比較して低い傾向がみられた $(p<0.1)$ 。皮下脂肪 厚は，I群が群 $(p<0.01)$ ， III群 $(p<0.01)$, IV 群 $(p$ $<0.05)$ と比較して有意に低值を示した。栄養素等摂取 量は 4 群間で有意差はみられなかった（結果示さず）。

\section{2 ）出生順位別解析（表 5 ）}

出生順位別に，「第 1 子群」(21名)，「第 2 子以降群」 （26名）の 2 群に分け, 各項目について比較した。その 結果, 皮下脂肪厚は「第 2 子以降群」が「第 1 子群」に 比べて有意に低值を示した $(p<0.01)$ 。出生時および 1 歳時の体重は 2 群間で有意差はみられなかった。栄養 素等摂取量は 2 群間で有意差はみられなかった（結果示 さず)。

\section{4. 考察}

\section{（1）対象者集団の現在の身体状況および栄養素等摂取}

\section{量}

本研究の対象者である管理栄養士養成課程に在籍して いる対象者52名の現在の身長, 体重, BMI, 皮下脂肪厚 （上腕三頭筋部皮下脂肪厚 + 肩甲骨下部皮下脂肪厚）は, 日本人の新身体計測基準值（JARD2001） ${ }^{18)}$ の18～24歳女 性の值とほぼ同値であった。栄養素等摂取量は,「日本 人の食事摂取基準（2015年版）」 ${ }^{19)}$ の18～24歳女性と比較 し, エネルギー, 鉄, カルシウム, マグネシウム, カリ ウム，食物繊維は基準を満たしておらず，「平成27年国 民健康 · 栄養調査」3) の15～19歳女性と比較しても全体 的に低值であった。 


\section{（2）女子大学生における出生時・乳児期の身体状況と 現在の状況との関連}

出生時体重の低值は冠動脈疾患 - 高血圧 - 糖尿病 - 脳 梗塞・脂質異常症の発症リスクと密接な関係があるとの 報告があるが20,211, 本研究では, 出生時体重は現在の身 体状況に影響を及ぼしていなかった。また，児の体格は 母親の体格の影響を受けるとの報告があるが222，本研究 では, 出生時体重に影響を与えるとされる母親の出産時 年齢や BMI は, 出生時体重との間に関連はみられず, 現在の身体状況にも影響はみられなかった。このことか ら, 出産時の母親の年齢や BMI は, 少なくとも本研究 のような集団においては, 出産後の児の成長に影響を及 ぼしていないことが示唆された。しかし，今回の調查対 象者は管理栄養士を目指す女子大学生であり, 食や健康 に関する知識をある程度備えており, 出生時体重が現在 の身体状況へ与える影響が少なかった可能性がある。ま た, 飢餓のような状況は含まれていないことから, 極端 な状況では異なった結論が得られる可能性がある。

出生時体重に影響を与えるもう一つの要因である妊娠 期体重増加量については, 娃娠中の体重増加量の少ない 妊婦では低出生体重児や在胎週数に比例して出生体重が 少ない SFD（small for date）児の出生割合が高いと報告 されている23)。今回の研究では, 出生時体重は, 妊娠期 体重増加量の少ない群で有意に軽かったものの, 現在の 身体状況まで影響を及ぼさず，出産時の母親の年齢や BMI と同様, 本研究のような集団に扔いては, 出生後 の児の成長に影響を及ぼしていないことが示された。 1988年と比較して2002年には, 娃娠期体重増加量の減少 に伴って出生時体重も減少しており, 低出生体重児の増 加が䯚念されている ${ }^{24)}$ 。わが国における妊娠中の体重増 加の推奨值は, 厚生労働省「健やか健康 $21 」^{25}$, 日本産 科婦人科学会周産期委員会 ${ }^{26)}$, 日本肥満学会 27 でそれぞ れ異なっており, 今後, 日本人を対象としたさらなるデー 夕の収集・蓄積が待たれる。

以上のことから, 出生時体重や, その要因とされる母 親の出産時年齢, BMI, 妊娠期体重増加量は, 少なくと も本研究の対象者のような女子大学生に扔いては現在の 身体状況には影響を及ぼしていないことが示された。ま た, 出生時体重は母親の娃娠期体重増加量と密接に関倸 していることから, 今後, やせの増加による母親の栄養 摂取不足に伴う低出生体重児の増加につながる可能性が あり，妊娠期の適切な生活習慣を身につけることや，現 在の適切な生活習慣形成が重要と考えられる。

\section{（3）現在の状況に対する乳児期栄養方法の影響}

内臟脂肪断面積㧍よび皮下脂肪厚は， II 群， III群，IV 群と比較して, I 群（出生後 3 か月間母乳のみで栄養を 受けた群）で有意に低值を示した。脂肪蓄積に与える影 響はこればかりではないが, 少なくとも本研究では, 乳 児期の栄養方法は，その時期の体重には影響を与えず,
現在の身体状況，特に内臟脂肪断面積㧍よび皮下脂肪厚 に影響を及ぼすことが示唆された。乳児期に打ける栄養 方法の違いが, その後の身体状況に及ほす影響は, 生後 早期の臨界期に受けた刺激が成長や代謝に影響するとい う「栄養のプログラミング理論」で説明されている28)。 機序は不明であるが，出生直後に高エネルギー・高たん ぱく質で育った場合，その後の脂質蓄積に影響を与える ことが報告されている29.30)。もう一つの原因に，母親の 知識・経験不足による「授乳量の不足感」がある。「平 成 27 年乳幼児栄養調査 $\rfloor^{15)}$ によると,「授乳量の不足感」 は, 母乳栄養 (31.2\%) や人工栄養 (16.3\%) と比較し て, 混合栄養 (53.8\%) で最も高く, 不足感を感じやす いことが報告されて抢り ${ }^{31}$ ，混合栄養では高エネル ギー・高たんぱく質摂取に陥りやすいことが示唆される。 実際に不足していることは少ないにもかかわらず不足分 を人工乳で補㧍うとするため, 乳児にとって量が過剩と なる場合があると考えられる。本研究においては, 哺乳 量を調査していないが, 要因の一つと推察される。

出生順位については, 第 1 子に比べて, 第 2 子以降で は皮下脂肪厚が低值を示した。出生順位別に栄養方法の 割合を見ると，3 3 月時点に扔いて，第 2 子では母乳栄 養のみで育った場合は $39 \%$ であるのに対し, 第 1 子では $16 \%$ と少なかった（結果示さず）。「平成17年乳幼児栄養 調査」に扔いても, 第 1 子は母乳栄養 $36.6 \%$, 混合栄養 $58.6 \%$ ，人工栄養 $4.9 \%$ であるのに対し，第 2 子は母乳 栄養 $47.3 \%$, 混合栄養 $48.2 \%$, 人工栄養 $4.4 \%$ であり, 第 1 子に扒いて母乳栄養の割合が低く, 本研究と同様の 傾向がみられている32。第 1 子と第 2 子以降で栄養方法 に差がみられる原因として, 初産の場合, 知識・経験不 足による「育児不安感」や「授乳量の不足感」を感じる 割合が高いため, 人工乳を与え過ぎてしまう可能性が指 摘されている ${ }^{33-35)}$ 。今回は, 女子大学生を対象とした調 查であるため授乳期の状況は把握できないが, 第 1 子に 打いて混合栄養が多く，母親の授乳に対する知識・経験 不足によって授乳量の不足感を感じることが多いため, 与える人工乳が過量となることが推察される。母親が授 乳に関する正しい知識を身につけられるような啓発教育 が重要と考えるが，母親が母乳を与えることができるか どうかは, 母親と児の出生時の健康状態にも影響される ため，個人にあった対応をするべきである。

\section{5. 結 論}

出生時体格や母親の年齢・BMI は, 少なくとも本研究 の対象者のような女子大学生の現在の身体状況には影響 を及ぼさないことが示された。しかし，今回対象者は研 究への同意が得られた管理栄養士養成課程に在籍する 52 名の女子大学生に限られることから今後さらなるデー夕 の蓄積, 検討が望まれる。一方, 早期の栄養方法の違い により, その後の身体状況, 特に内臓脂肪断面積拉よび 皮下脂肪厚に影響を及ぼすことが示唆された。今後, 将 
来に及ぼす影響を調査するための縦断的な調査が待たれ るが，いずれにせよ，妊娠期や授乳期に，母親が適切な 生活習慣を保持し，その後の児の生活習慣を形成するこ とが重要であり, 女子大学生が将来の妊娠・出産・育児 に備えて正しい知識を持つための栄養教育の必要性が示 唆された。

\section{謝辞}

本研究は, 椙山女学園大学「平成25年度学園研究費助 成金 B」による助成を受けた。

研究の補助をして頂いた長谷川綾さん, 服部綾子さん に感謝いたします。

\section{文献}

1）厚生労働省：平成27年人口動態調查報告, http://www. mhlw.go.jp/toukei/list/81-1.html（2017年 2 月28日）

2 ）母子衛生研究会編：母子保健の主なる統計, 母子保健事 業団, 東京, p.46-47 (2012)

3 ）厚生労働省：平成27年国民健康 - 栄養調査報告, http:// www.mhlw.go.jp/stf/houdou/0000142359.html（2017 年 3 月 6 日）

4 ) Kubota,K., Itoh,H., Tasaka,M.,et al.: Changes of maternal dietary intake, bodyweight and fetal growth throughout pregnancy in pregnant Japanese women, J Obstet Gynaecol Res, 39 (9), 1383-1390 (2013)

5 ) 中村敬：最近の低出生体重児出生率上昇の理由, 治療, 77 ( 3 )，1202-1204（1995）

6 ）中村敬：妊娠中の喫煙と周産期異常，母子保健情報，37, 71-74 (1998)

7 ) Dewey,K.G.: Is breastfeeding protective against child obesity?, J Hum Lact, 19, 9-18 (2003)

8 ) Ravelli,A.C., van der Meulen,J.H., Osmond,C., et al.: Infant feeding and adult glucose tolerance, lipid profile, blood pressure, and obesity, Arch Dis Child, 82, 248-252 (2000)

9) Martin,R.M., Ness,A.R., Gunnell, D., et al.: Does breastfeeding in infancy lower blood pressure in children? The Avon Longitudinal Study of Parents and Children (ALSPAC), Circulation, 109, 1259-1266 (2004)

10) Singhal,A., Cole,T.J., Fewtrell,M., et al.: Breastmilk feeding and lipoprotein profile in adolescents born preterm: follow-up of a prospective randomized study, Lancet, 363, 1571-1578 (2004)

11) Thorsdottir,I., Gunnarsdottir,I., Palsson,G.I.: Association of birth weight and breast-feeding with coronary heart disease risk factors at the age of 6 years, Nutr Metab Cardiocasc Dis, 13, 267-272 (2003)

12）厚生省児童家庭局：母乳運動の推進について, 小児保健 研究，34（1)，46-48 (1975)

13）厚生労働省：授乳・離乳の支援ガイド, http://www. mhlw.go.jp/shingi/2007/03/s0314-17.html (2013年12月 2 日)

14） WHO/UNICEF：母乳育児を成功させるための10力条, http://www.unicef.or.jp/about_unicef/about_hospital.html (2013年12月 2 日)

15）厚生労働省：平成27年乳幼児栄養調査報告, http://www. mhlw.go.jp/stf/seisakunitsuite/bunya/0000134208.html (2017年 2 月28日)

16）厚生労働省：妊産婦のための食生活指針, http://www. mhlw.go.jp/houdou/2006/02/h0201-3a.html(2013年12月 2 日)

17）天冨美穪子, 東真由美: 生後 3 か月間の乳汁栄養の推移 一母乳育児に対する母親の意識と行動からの考察一, 大阪 教育大学紀要, 38 (1), 113-127 (1989)

18）日本人の新身体計測基準值（JARD2001）, メディカルレ ビュー社, 大阪 (2002)

19）厚生労働省：日本人の食事摂取基準（2015年版）, http:// www.mhlw.go.jp/stf/seisakunitsuite/bunya/kenkou_iryou/ kenkou/eiyou/syokuji_kijyun.html（2017年 7 月31日）

20) de Boo,H.A., Harding,J.E.: The developmental origins of adult disease (Barker) hypothesis, Austral New Zealand J Obstet Gynecol, 46, 4-14 (2006)

21) Tamakoshi,K., Yatsuya,H., Wada,K., et al.: Low birth weight is associated with reduced adiponectin concentration in adult, Ann Epidemiol, 16 (9), 669-674 (2006)

22) Murrin,C.M., Kelly,G.E., Tremblay,R.E., et al.: Body mass index and height over three generations: evidence from the lifeways cross-generational cohort study, BMC Public Health, 12, 81 (2012)

23）上田康夫, 丸尾原義, 新谷潔：母体体重管理のプロスペ クティブな指標としての妊娠16週体重増加量の意義に関す る検討, 日本産科婦人科学会雑誌，53，980-988（2001）

24）上田康夫, 丸尾原義, 足高義彦：現行母体至適体重増加 基準の妥当性に関する研究—1988年からの15年間における 母児体重の変遷からの再評価, 産婦人科の進歩, $57(2)$, 121-130 (2006)

25）厚生労働省：妊産婦のための食生活指針「健やか親子 $21 」$ 推進検討会報告書, http://www.mhlw.go.jp/houdou/2006/02/ h0201-3a.html.（2013年12月 2 日）

26）中村正雄：妊娠中毒症の栄養管理指針，日産婦誌，51, 507-510 (1999)

27）日本肥満学会編：肥満症治療ガイドラインダイジェスト 版, 協和企画, 東京, p.125-126（2007）

28) Lucas,A.: Programming by early nutrition in man, Wiley and Sons, 38-55 (1991)

29) Metges,C.C.: Longterm effects of pre- and postnatal exposure to low and high dietary protein levels. Evidence from epidemiological studies and controlled animal experiments, Adv Exp Med Biol, 569, 64-68 (2005)

30) Scaglioni,S., Agostoni,C., Notaris,R.D., et al.: Early macronutrient intake and overweight at five years of age, Int J Obes, 24, 777-781 (2000)

31) 石井美里：生後 9 か月までの母乳栄養継続状況の調査, 東海大学健康科学部紀要, 9, 51-56 (2004)

32）厚生労働省: 平成17年乳幼児栄養調查報告, http://www. mhlw.go.jp/houdou/2006/06/h0629-1.html(2017年 2 月28日)

33）武本茂美, 中村幸代: 児の栄養法別による育児不安抒よ び対児感情の関連, 日本助産学会誌, 25 ( 2)，225-232 (2010)

34）水上明子, 谷口まり子, 馬場直美ほか：産後の母親の育 児不安, 熊本大学教育学部紀要, 43，89-97 (1994)

35）島田三恵子，渡部尚子，神谷整子ほか：産後 1 か月間の 母子の心配事と子育て支援のニーズに関する全国調査一初 経産別, 職業の有無による検討一, 小児保健研究, 60（５), 671-679 (2001) 